IIILE: SOME ASPECTS OF MATERIALS DEVELOPMENT FOR SODIUM HEATED STEAM GENERATORS

AUIzORS: Prodyot Roy and C.N. Spalaris

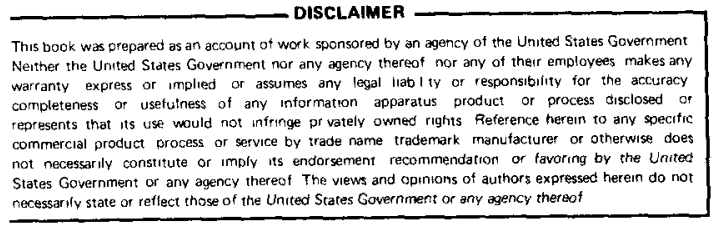

Prepared for presentation at:

ANS International Conference, Materials Performance in Nuclear Steam Generators Conference

Eeld 10: St. Petersburg, Florida

CI57, Seate

os: October 1980

Thts paper contatos materlal resulting from work performed for: US Department of Energy

Doder Coneace No. DE-AT03-76SF70030

Bader DA Easik

This paper has been authored by a contractor of the U.S. Government under contract No.DE-AT03-76SF70030 Accordingly, the U.S. Government retains a nonexclussve, royaly-jree license to publish or reproduce the published form of this contribution, or allow others to do so, for U.S. Governnent purposes.

\title{
GENERAL STECTRIC
}

ADPANCEDREACIOR STSIEMS DE PARIMENT SONRTPALE, CAIIFORAIA 


\section{DISCLAIMER}

This report was prepared as an account of work sponsored by an agency of the United States Government. Neither the United States Government nor any agency Thereof, nor any of their employees, makes any warranty, express or implied, or assumes any legal liability or responsibility for the accuracy, completeness, or usefulness of any information, apparatus, product, or process disclosed, or represents that its use would not infringe privately owned rights. Reference herein to any specific commercial product, process, or service by trade name, trademark, manufacturer, or otherwise does not necessarily constitute or imply its endorsement, recommendation, or favoring by the United States Government or any agency thereof. The views and opinions of authors expressed herein do not necessarily state or reflect those of the United States Government or any agency thereof. 


\section{DISCLAIMER}

Portions of this document may be illegible in electronic image products. Images are produced from the best available original document. 
SOME ASPECTS OF MATERIALS DEVELOPMENT

FOR SODIUM HEATED STEAM GENERATORS

Prodyot Roy and C. N. Spalaris

General Electric Company

Advanced Reactor Systems Department

175 Curtner Avenue

San Jose, CA 95125

P. Roy

(408) $925-5181$ 

SOME ASPECTS OF MATERIALS DEVELOPMENT

FOR SODILM HEATED STEAM GENERATORS

Prodyot Roy and C. N. Spalaris.

\begin{abstract}
A development program was undertaken to support the materials selection for steam generator piping and IHX which are to be used in Liquid Metal Fast Breeder Reactors (LMFBR). Four major topics have been reviewed, describing the results obtained as well as the direction of future tests. These topics are: carbon transport in sodium, effect of carbon loss/gain upon materials in the reactor Intermediate Heat Transport System (IHTS), corrosion fatigue and aqueous corrosion.

Thus far, the results on hand support the initial assumptions made in specifying the use of $2-1 / 4 \mathrm{Cr}-1$ Mo as the construction material for the evaporator and superheater and Type 316 piping of the IHT system.

Future direction of the experimental programs is to further verify the materials choice and to also obtain information which will be essential during the plant installation, operation and reliability of the components.
\end{abstract}




\section{INTRODUCTION}

Reliability of sodium heated steam generators is the key element to successful demonstration of Liquid Metal Fast Breeder Reactor (LMFBR). The United States programs have selected unstabilized 2-1/4Cr-IMo as the construction material for both evaporator and superheater portions of steam generators.

Development work on steam generator materials is directed towards characterization and verification of materials properties to ensure high reliability during the service life of the reactor. The purpose of this paper is to describe some of the highlights of the development work being conducted at General Electric, featuring the following topics:

- Carbon Transport in the bimetallic Intermediate Heat Transport System (IHTS).

- Effect of decarburization and thermal aging on the mechanical properties of steam generator materials.

- Corrosion fatigue of 2-1/4Cr-1Mo steel in high temperature caustic environment.

- Steam and waterside corrosion of 2-1/4CI-1Mo steel.

II. CARBON TRANSPORT IN IHTS

The use of $2-1 / 4 \mathrm{Cr}$-1Mo steel in steam generators is tempered with the concern for its tendency to decarburize with concurrent carburization of the austenitic stainless steel components in the intermediate heat transport circuit. The extent of carburization of austenitic steels for the service life of the reactor was estimated by Snyder et al. (1) Experimental determination of decarburization kinetics of ferritic steel and the extent of carburization of austenitic steel in a bimetallic flowing sodium system designed to simulate 
the IHTS of LMFBR is being conducted at CEA and EDF (France)(2) and General Electric Co. (USA).(3) Although studies on this subject are conducted throughout the world, only data obtained from prototypical IHTS sodium loops will be discussed in this paper.

II.A. Data Analysis Method for Decarburization of 2-1/4Cr-IMo

Earlier, (4) decarburization of $2-1 / 4 \mathrm{Cr}-1$ Mo steel was assumed to be a diffusion control process; thus, all the data were analyzed using the following decarburization rate expression:

$$
K=\frac{M}{\sqrt{t}}
$$

where $\mathrm{K}=$ Decarburization rate constant $\mathrm{gm} / \mathrm{cm}^{2} \mathrm{sec}^{1 / 2}$

$M=$ Mass of carbon loss $\mathrm{gm} / \mathrm{cm}^{2}$

$t=$ Time in sec.

In order to calculate the carbon loss of $2-1 / 4 \mathrm{Cr}-1$ Mo steam generators, Rrankota and Armijo(4) assumed that decarburization rate $K$ is invariant with time, and they projected a carbon loss for ferritic steam generator tubes for the service life of the reactor assuming a constant value of $\mathrm{K}$. More recent studies show that the decarburization of $2-1 / 4 \mathrm{Cr}-1$ Mo is not a diffusion control process; rather, decomposition of carbides governs the carbon movement in the steel. Consequently, the type of melting practice, chemical composition and heat treatment, all of which determine the composition and morphology of the carbide, will have major effects on the kinetics of decarburization of $2-1 / 4 \mathrm{Cr}-1$ Mo steel in sodium. (5)

II.B. Experimental

\section{II.B.1. Loop Description}

An Intermediate System Mockup Loop (ISMI) was designed to simulate an IHTS of an LMFBR. (3) This was accomplished by simulating both materials 
temperature and sodium velocity in ISM. The surface area ratio of $2-1 / 4 \mathrm{Cr}-$ IMO ferritic and austenitic steels at temperatures above $427^{\circ} \mathrm{C}$ in ISML closely approaches that found in an LMFBR. A more detailed description of the loop is given elsewhere. (6)

\section{II.B.2 Materials}

For decarburization study, tubular (15.9 OD by 2.77 wall) specimens exposed to flowing sodium only on the outside diameter were used to simulate typical steam generator geometry situations. Both electro-slag remelted (ESR) and vacuum arc remelted (VAR) $2-1 / 4 \mathrm{Cr}-1$ Mo steel samples produced from a single air melted ingot were used in the loop. In order to study the carburization of stainless steels, both tube and foil materials, including $304 \mathrm{~L}$ and $326 \mathrm{~L}$ were exposed to flowing sodium.

II.C. Results

II.C.I. Decarburization of 2-1/4Cr-1Mo

Fig. 1 shows a plot of time dependence of decarburlzation of 2-1/4Cr-1Mo steel tubes exposed at $524^{\circ} \mathrm{C}$ in ISML (m versus $\sqrt{t}$ ). The data show that the diffusion model for decarburization of $2-1 / 4 \mathrm{Cr}-1$ Mo steel is not followed. Depending on which set of data is used, the calculated $\mathrm{K}$ value for the VAR tubes can vary from $4.4 \times 10^{-8}$ to $7.9 \times 10^{-8} \mathrm{gm} / \mathrm{cm}^{2}-\mathrm{sec}^{1 / 2}$. Fig. 1 also shows that for equivalent sodium exposure the decarburization rate of ESR material is about a factor of $\sim 2$ to 4 times slower than VAR material at $524^{\circ} \mathrm{C}$. Furthermore, it is obvious from the figure that the rate of decarburization of both materials is decreasing with time.

In order to compare the present data with the data obtained by Baque et al (2) from Carnacier loop and compare the temperature dependence of decarburization, $K$ values for ESR and VAR tube samples exposed in ISML to 15148 
hours are shown, along with the French data, (2) on an Arrhenius plot in Fig. 2. In this case the $K$ values were determined by calculating the slope of the line drawn from the data through the origin in Fig. 1. Figure 2 confirms that VAR steel decarburizes at a faster rate than ESR material, and results indicate that there is very little temperature dependence in decarburization rate of VAR material. Also shown in the figure are the French decarburization data(2) from Camacier loop indicating good agreement with data obtained in ISML.

\section{II.C.2. Carburization of Stainless Steel}

The carbon analysis of 304 foils exposed in ISM indicates that at least up to 5000 hours the carburization of this material can be described by a parabolic time dependency. Assuming this relationship, the carburization rate constant $\mathrm{K}\left(\mathrm{gm} / \mathrm{cm}^{2}-\mathrm{sec}^{1 / 2}\right)$ for $304 \mathrm{SS}$ between temperature regions of $350-524^{\circ} \mathrm{C}$ is plotted on Fig. 3. The figure indicated that, initially, there is very little temperature dependence of carburization of stainless steel in ISML. This is very similar to the results of Baque et al(2) for carburization of stainless steel after 215,000 hours of loop operation. However, carbon profile analysis of the samples in ISM at higher temperatures $\left(2450^{\circ} \mathrm{C}\right)$ for times greater than $\sim 5000$ hours shows that stainless steel samples have started to decarburize, (7) indicating the activity of carbon in ISML is decreasing with time. This observation is not consistent with the assumption of Snyder et al, (1) that the carbon activity at any given temperature in a reactor will remain constant throughout the life of the plant. 
III. EFFECT OF DECARBURIZATION AND THERMAL AGING ON MECHANICAL PROPERTIES OF 2-1/4Cr-1MO STEEL

One of the main concerns using 2-1/4Cr-1Mo steel for sodium heated steam generators is the reduction in strength of this material due to loss of carbon. To date, the degradation of the properties of $2-1 / 4 \mathrm{Cr}-1$ Mo steel components exposed to decarburizing sodium condittons has been attributed to loss of carbon from the steel. The contribution of thermal aging has either been neglected or minimized. However, as the control data become available, the importance of thermal aging in understanding the decarburization behavior of 2-1/4Cr-1Mo steel has been demonstrated.

III.A. Experimental

III.A.1. Sodium Exposure

In-sodium decarburization of the tensile and creep of ESR 2-1/4Cr-IMo specimens was performed in a Ti-gettered static sodium retort at temperatures. The materials used in this study were obtained from two different vendors (Patco $\mathrm{Cl} 003$ and Cartech 91505). The tensile properties were determined using flat coupons and tubing; whereas the uniaxial creep properties were determined using tubing material. All the specimens were given an isothermal anneal plus post weld heat treatment (IA + PWHT) as follows:

- $\quad 927^{\circ} \mathrm{C}$ for $30 \mathrm{~min}$.

- Furnace $\mathrm{Cool}$ to $704^{\circ} \mathrm{C}$ in $90 \mathrm{~min}$.

- Isothermal Hold at $704^{\circ} \mathrm{C}$ for 90 min.

- Air Cool to Room Temperature

- $727^{\circ} \mathrm{C}$ for 4 hours

- Cool to Room Temperature. 
III.B. Results

Only the highlights of data and major conclusions are presented in the paper. A more detailed description of the results and data analysis is reported in separate documents. (ㅇ)

III.B.1. Tensile Properties at $510^{\circ} \mathrm{C}$

The $510^{\circ} \mathrm{C}$ strength properties of decarburized and aged coupon specimens of ESR 2-1/4Cr-1Mo steel are shown in Fig. 4. The data show a decrease in both yield and ultimate tensile strength due to thermal aging and decreasing carbon content. For ease of comparison, the data for the aged/control specimens (exposed to inert atmosphere for similar length of time and temperature of decarburization) are plotted along with decarburized specimens. It is to be noted that the aged specimens have a carbon content equal to the initial material. The comparison of decarburized versus aged data indicates that thermal aging is predominantly responsible for reduction of strength. For comparison, the mean difference in ultimate tensile strength, decarburized versus control, is $-16.2 \mathrm{MPa}$. The mean difference in yield strength is -10.8 MPa. A duplicate decarburized specimen was reheat treated (IA + PWHT); this reheat treatment produced a partial recovery of the $510^{\circ} \mathrm{C}$ strength properties, as shown in Fig. 4 (arrow). Therefore, it appears that there is only a minor dependence of short-term strength properties on residual carbon content at $510^{\circ} \mathrm{C}$.

\section{III.B.2. Creep Properties at $510^{\circ} \mathrm{C}$}

The $510^{\circ} \mathrm{C}$ uniaxial creep data for decarburized and aged tubing specimens of ESR 2-1/4Cr-1Mo steel exhibited trends similar to the high temperature tensile data. The stress-rupture results obtained from the creep tests of 
decarburized and control (thermally aged) specimens are shown in Fig. 5, together with three lines derived from an ORNL correlation. (8) The results show that the thermal aging and decarburization decreased the short-term stress-rupture properties of $2-1 / 4 \mathrm{Cr}-1$ Mo steel. The creep-rupture strength of decarburized material was slightly less than thermally aged material. The present observation is consistent with conclusions made by Klueh. (9) Hence, it appears from the present data that effect of decarburization and thermal aging on long-term creep properties needs further evaluation.

IV. CORROSION FATIGUE OF 2-1/4Cr-1MO STEEL IN HIGH TEMPERATURE CAUSTIC Departure from nucleate boiling (DNB) may occur in some of the IMFBR evaporators. Under certain conditions, the DNB region can be localized causing thermal strain and load cycling within the localized area where water impurities may concentrate and protective oxide layer may exfoliate. The most likely impurity in all volatile treated water of LMFBR with a condensate polishing system is sodium hydroxide. The cyclic strains which occur at frequencles up to about $1 \mathrm{~Hz}$ are considered to be less than 0.5 percent; consequently, the effect due to caustic environment would be primarily in the high cycle fatigue regime $\left(\geq 10^{6}\right.$ cycles). To evaluate the potential degradation under these conditions, it was thought prudent to initiate corrosion fatigue tests of $2-1 / 4 \mathrm{Cr}-1$ Mo in high temperature caustic environment. IV.A. Experimental

\section{IV.A.I. Autoclave Design}

All the tests were performed in 8 litre Alloy 800 autoclave shown in Fig. 6. This autoclave was specially designed for operation at $316^{\circ} \mathrm{C}$ at 1600 psi with capability of conducting fully reversible fatigue tests. 
Initially, the autoclave was designed to run the tests under deflection control mode. The original design has since been modified so that the true strain on the specimens can be measured directly during the test so that uncertainty in the strain measurement has been considerably minimized. IV.A.2. Materials Specimen Geometry and Test Conditions Electroslag and vacuum arc remelted 2-1/4Cr-1Mo steel with similar heat treatment described in Section III were selected for-the corrosion fatigue tests. Buttonhead tensile specimens with gauge length to diameter ratio (L/D) of 2.0 were used for the fatigue tests. All the tests were conducted at 5\% $\mathrm{NaOH}$ at $316^{\circ} \mathrm{C}$ and $1600 \mathrm{psi}$. Tests were run at a frequency of $1 \mathrm{~Hz}$ using triangular wave form over a strain range of 0.1 to 1.0 percent.

IV.B. Results

Initially, the corrosion fatigue tests were controlled by specimen displacement signal and monitored by load signal. The load signal was then related to strain by a cyclic stress-strain relationship developed from a monotonic and cyclic data for IA + PWHT ESR 2-1/4Cr-IMo steel obtained at ORNL and General Electric $(\underline{10})$ as shown in Fig. 7. The results of load and strain controlled fatigue tests conducted to date are plotted in Fig. 8 in reference to air curve developed for: (a) IA terfal at $316^{\circ} \mathrm{C}$, (b) IA+ PWHT material at $371^{\circ} \mathrm{C}$, and (c) the design allowable curve (2-20 safety factor). (10) The results shown in Fig. 8 are found to lie above the proposed design allowable fatigue curve for the steam generator tubes. However, the high cycle data for this study show a reduction in the endurance limit of the alloy due to caustic environment. Although encouraging, this work is continuing with higher caustic concentration at higher number of cycles $\left(\geq 10^{6}\right)$. 
V. STEAM AND WATERSIDE CORROSION OF 2-1/4Cr-1MO STEELS

In both superheater and evaporator environment, the basic equation for the corrosion of low alloy steel is:

$$
3 \mathrm{Fe}(\mathrm{s})+4 \mathrm{H}_{2} \mathrm{O}(\mathrm{g}, 1)=\mathrm{Fe}_{3} \mathrm{O}_{4(\mathrm{~s})}+4 \mathrm{H}_{2(\mathrm{~g})} .
$$

In superheater, gaseous steam reacts with steel surfaces, while in an evaporator the medium is deoxygenated $(<10 \mathrm{ppb}$ ), alkaline ( $\mathrm{pH} 9.3-9.6)$ water.

Because of the difference in the physical properties of two fluids and the difference in corrosion mechanism, the reduction of data presented is necessarily separated according to service conditions.

7.A. Steam Corrosion of $2-1 / 4 \mathrm{Cr}-1$ Mo Steel

7.A.1. Isothermal Corrosion

Considerable data have been collected on corrosion response of $2-1 / 4 \mathrm{Cr}-$ IMo steel under conditions simulating the steam exit region of an LMFBR superheater, where isothermal corrosion condition prevails.(11-15) Isothermal corrosion relationship thus derived is based on analysis of available data in the temperature range of $\sim 400-593^{\circ} \mathrm{C}$. It has been shown that the corrosion rate is initially high and decreases with time. (11-15) The decrease in the corrosion rate is attributed to the formation of magnetite $\left(\mathrm{Fe}_{3} \mathrm{O}_{4}\right.$ ) scale which impedes further oxidation (eq. 2). Furthermore, all the corrosion experiments show that after the initial high parabolic rate the corrosion rate becomes essentially linear. Thus, the high temperature steall corrosion data for 2-1/4Cr-1Mo steel are described by an expression of the form:

$$
\Delta W=W_{0}+R t
$$

where $\Delta W=$ total metal penetration

$$
W_{0}=\text { intercept of linear rate }
$$


$t=t i m e$

$\mathbf{R}=$ best fit linear rate after apparent onset on linearity.

The calculated constants $R$ and $W_{0}$ from all the available data are shown in Figs. 9 and 10, respectively, as functions of inverse temperature. The regression lines for the two data sets are also plotted on the figures, and the equations for these curves can be expressed as:

$$
\begin{aligned}
& R=15.7 \exp \left(-\frac{7517}{T}\right) \\
& W_{0}=230.6 \exp \left(-\frac{9367}{T}\right)
\end{aligned}
$$

where $R$ = Iinear rate, $c m / y r$

$$
\begin{aligned}
& W_{0}=\text { intercept, } \mathrm{cm} \\
& \mathrm{T}=\text { absolute temperature, }{ }^{\circ} \mathrm{K} .
\end{aligned}
$$

It should be recognized that the data presented in Figs. 9 and 10 have a built-in uncertainty, since different methods such as (a) scale thickness, (b) weight gain, and (c) descaled weight loss were used to establish the metal penetration. Methods (a) and (b) require assumptions regarding scale composition, density, and exfoliation behavior.

V.A.2. Effect of Heat Flux in Steam Corrosion

Exfoliation of the protective oxide was observed in corrosion experiments for $2-1 / 4 \mathrm{Cr}-1 \mathrm{Mo}$ steel at $126 \mathrm{~kW} / \mathrm{m}^{2}$ at metal temperatures of $522^{\circ} \mathrm{C}$. One set of descaled weight loss data for corrosion of $2-1 / 4 \mathrm{Cr}-1$ Mo steel was collected from tubular specimens exposed at $1000,3000,6000$ and 10,000 hours and are available in the literature.(13) In comparable experiments under 1sothermal conditions, the observed corrosion rate was as much as 1.7 times lower than the corrosion under heat flux conditions. When these data are plotted 
(Fig. 9), the emerging picture is not as clear, and extrapolation to design life of the reactor is difficult.

Previous experience with corrosion of austenitic alloys in superheated steam also indicated that the presence of heat flux causes the corrosion rate to increase by factors of 1.0-2.0, depending upon heat flux conditions. $(16,17)$ In view of insufficient data, it is recommended that a factor of 1.5 be applied to the isothermal corrosion rate expression (equation) to account for the effect of heat flux, thus providing a built-in conservatism in any corrosion assessment.

\section{VI.A.3. Aqueous Corrosion}

Available data which determine the aqueous corrosion of $2-1 / 4 \mathrm{Cr}-1$ Mo steel are sparse. To obtain a rational extrapolation which would be applied to design allowables, an estimate was obtained from the hydrogen permeation rate on the sodium side of the sodium heated steam generators. Roy and Rodgers(18) have collected steady-state hydrogen permeation rate data from various operating LMFBR steam generators. Furthermore, it has been shown that most of the hydrogen produced by corrosion according to eq. 2 diffuses through the tube into sodium. (19) Thus, the observed hydrogen permeation rate in operating steam generators, converted into corrosion rates, are shown in Table I. Included in Table I also are corrosion rates measured by descaling of a test evaporator $(20)$ and by oxide thickness measurements of a test section. (12) The agreement between the indirect method (hydrogen permeation) and direct measurements is excellent. 


\section{CONCLUSION AND RECOMMENDATION}

- All prototypic 2-1/4Cr-1Mo tube material will decarburize by 150-200 ppm at the startup - regardless of initial carbon level. Thereafter, however, provided the material is isothermally annealed, the carbon loss will proceed at a slower rate.

- An empirical model for decarburization of 2-1/4Cr-1Mo steel does not appear feasible at present. The previous assumption that decarburization of rate constant $R$ is a diffusion controlled process and thus the decarburization is invariant with time is not correct.

- Attempts to calculate long-term carbon loss using a constant $R$ value obtained from a short-term test will lead to an erroneous conclusion. However, since the value of $K$ is decreasing with time, calculation of long-term carbon loss using higher $K$ values will be conservative.

- ESR 2-1/4Cr-1Mo steel decarburizes at a much slower rate than VAR material. Since both materfals were remelted from the same ingot and were given identical heat treatment, the large difference in the decarburization kinetics can only be attributed to composition of the carbides due to the presence or absence of minor elements.

- After 19,000 hours of ISML operation, it appears that carbon acţivity in sodium decreases with time, as Indicated by decarburization of Type 304 exposed at temperatures above $450^{\circ} \mathrm{C}$.

- The present data suggest that the stainless steel components in IHTS located at temperatures above $450^{\circ} \mathrm{C}$ will not carburize after several thousand hours of operation. This conclusion does not support the previous assumption that the activity of carbon in IHTS will be maintained at a constant high level throughout the service life of the reactor. 
- It appears that thermal aging (without carbon loss) causes a significant reduction in ultimate and yield strength of $2-1 / 4 \mathrm{Cr}-1$ Mo steels. The degradation of UTS and YS due to the combined effect of thermal aging and decarburization must be accounted for in the steam generator design.

- Both thermal aging and decarburization decrease the creep-rupture properties of 2-1/4Cr-1Mo steel. The creep properties of decarburized material were lower than those of the thermally aged material. Hence, the effect of decarburization on the degradation of long-term creep properties of 2-1/4CrIMo steels needs detail analysis.

- High cycle corrosion fatigue tests in caustic environment at $316^{\circ} \mathrm{C}$ indicate a degradation of fatigue life when compared to data obtained in air environment. However, the degradation is not sufficient to cause an alarm that DNB condition will lead to a disabling episode.

- Although the corrosion fatigue test results are encouraging, more high cycle fatigue data at cycles $>10^{6}$ in higher caustic concentrations are needed to confirm the safety of the steam generator under DNB conditions. - The recomended corrosion rate for $2-1 / 4 \mathrm{Cr}-1$ Mo steel, under superheat conditions and maximum metal temperature of $502^{\circ} \mathrm{C}$, is $25 \mu \mathrm{m}$ per year. - The recommended average corrosion allowance for the evaporators is $25 \mu \mathrm{m} /$ year.

- It is understood that the $25 \mu \mathrm{m} /$ year metal penetration will not adversely affect the safe operation of the evaporators. However, the high hydrogen burden in the IHTS sodium resulting from permeation of hydrogen generated from corrosion will have a significant impact on leak detectlor. devices, based on hydrogen concentration measurements and design of the purification system for IHTS. 


\section{REFERENCES}

1. R. B. SNYDER, K. NATESAN, and T. F. KASSNER, "A Generalized Method of Computing Carbon Diffusion Profiles in Austenitic Stainless Steel Exposed to a Sodium Environment," ANL 8015 (June 1973).

2. P. BAQUE et al., "Carbon Transfer Behavior Between 2-1/4Cr-1Mo Alloy and Austenitic Steels," Proc. Int. Conf. on Liquid Metal Tech. In Energy Production, Conf. 760503-P2, pp. 834-839 (May 1976).

3. C. N. SPALARIS, K. D. CHALLENGER, D. DUTINA, and P. RING, "Sodium Heated Steam Generators Near Term and Projected Information Needs - Ferritic Steels," Trans. BNES Int. Conf. on Ferritic Steels for Fast Reactor Steam Generators, Paper No. 9 (Jume 1977).

4. J. L. KRANKOTA and J. S. ARMIJO, "The Kinetics of Decarburization of 2-1/4Cr-1Mo Steel in Sodium," Nuc1. Tech., 24, pp. 225-233 (November 1974). 5. C. TYZACK and A. W. THORLEY, Trans. BNES Int. Conf. on Ferritic Steels for Fast Reactor Steam Generators, Paper No. 39 (Jume 1977).

6. J. L. KRANKOTA and K. D. CHALLENGER, "Carbon Transport and Materials Properties Degradation in a Model of Clinch River Breeder Reactor Secondary Sodium System," Proc. Int. Conf. on Liquid Metal Tech. in Energy Production, pp. 819-825 (May 1976).

7. I. V. HAMPTON, C. N. SPALARIS, P. ROY, and S. KANO, "Carbon Transport in a Bimetallic Sodium Loop Simulating the Intermediate Heat Transport System of a Liquid Metal Fast Reactor," presented at Second Int. Conf. on Liquid Metal Tech. In Energy Production, Paper No. II-4 (April 1980).

8. G. P. WOZADLO, L. V. HAMPTON, and P. ROY, "Decarburization and Thermal Aging - Their Effect Upon 2-1/4Cr-1Mo Steel Mechanical Properties," ibid, Paper No. II-1. 
9. R. L. KIUEH, J. Nuc1. Mat., 54 (1) (November 1974).

10. A. E. MCILREE, P. P. PIZZO, and M. E. INDIG, "Corrosion Fatigue of 2-1/4Cr-1Mo at $316^{\circ} \mathrm{C}, "$ International Corrosion Forum sponsored by NACE, March 12-26, 1979, Atlanta, Georgia, Paper No. 221.

11. F. EBERLE and J. H. KITTERMAN, "Behavior of Superheated Alloys in High Temperature, High Pressure Steam," ASME publication (1968).

12. C. N. SPALARIS, "Corrosion Issues in Steam Generators of Fast Breeder Reactor System," Materials and Corrosion Problems in Energy System sponsored by NACE, February 3-7, 1980, New Orleans, Louisiana.

13. J. H. DEVAN and J. C. GRIESS, Nuc1. Tech., 28 (3) (March 1976).

14. F. EBERLE and C. H. ANDERSON, ASME 61-PWR-3.

15. I. A. ROHRIG, R. M. VANDUZER, and C. H. FELLOWS, Trans. ASME, 66 (1944).

16. W. J. PEARL et al., GEAP-4760, General Electric Co. (March 1965).

17. S. LEISTIKOW, Untersuchung Wichteger Einflussgrossen auf Technische Korrosionverhalten der Legierung Incoloy 800 in Uberhintztem Wasserdamp, Reaktortagung, Berlin 2.-5.4.74 (1974).

18. P. ROY and D. N. RODGERS, Nucl. Tech., 39 (1978).

19. L. TOMLINSON et al., "Waterside Corrosion of Ferritic Steel Under High Heat Flux Conditions," Trans. BNES Int. Conf. on Ferritic Steels for Fast

Reactor Steam Generators, Paper No. 59.

20. D. N. RODGERS, D. DUTINA, and I. V. HAMPTON, 17 th National Heat Transfer Conference, Salt Lake City, Utah, August 14-17, 1977. 
Table I

EVAPORATOR CORROSION DATA (18)

\begin{tabular}{|c|c|c|c|}
\hline Factlity & Temp.,${ }^{\circ} \mathrm{C}$ & $\begin{array}{r}\text { Steady State } \mathrm{H}_{2} \text { Flux } \\
\mathrm{gmH} / \mathrm{cm}^{2}-\sec \times 10^{11} \\
\end{array}$ & $\begin{array}{l}\text { Corrosion Rate } \\
\mathrm{cm} / \mathrm{yr} \times 10^{3} \\
\end{array}$ \\
\hline Phen1x Prototype & 405* & 2.5 & 2.10 \\
\hline Phenix & 405* & 2.1 & 1.80 \\
\hline PFR & $413 *$ & 3.3 & 2.80 \\
\hline Monju Prototype & $400^{*}$ & 1.8 & 1.50 \\
\hline GE-DNB (15) & 406 & -- & 1.50 \\
\hline GE-DNB（15) & 366 & -- & 1.80 \\
\hline GE-DNB（15) & 326 & -- & 2.00 \\
\hline WARD-SSGM (16) & 402 & & 1.50 \\
\hline
\end{tabular}

Comments

Calculated from $\mathrm{H}_{2}$ Flux Data

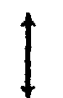

Calculated from $\mathrm{H}_{2}$ Flux Heat

Descaled Tube ID Measurement

Descaled Tube ID Measurement

Descaled Tube ID Measurement

Scale Thtckness

*Average of evaporator sodium Inlet and extt temperatures. 


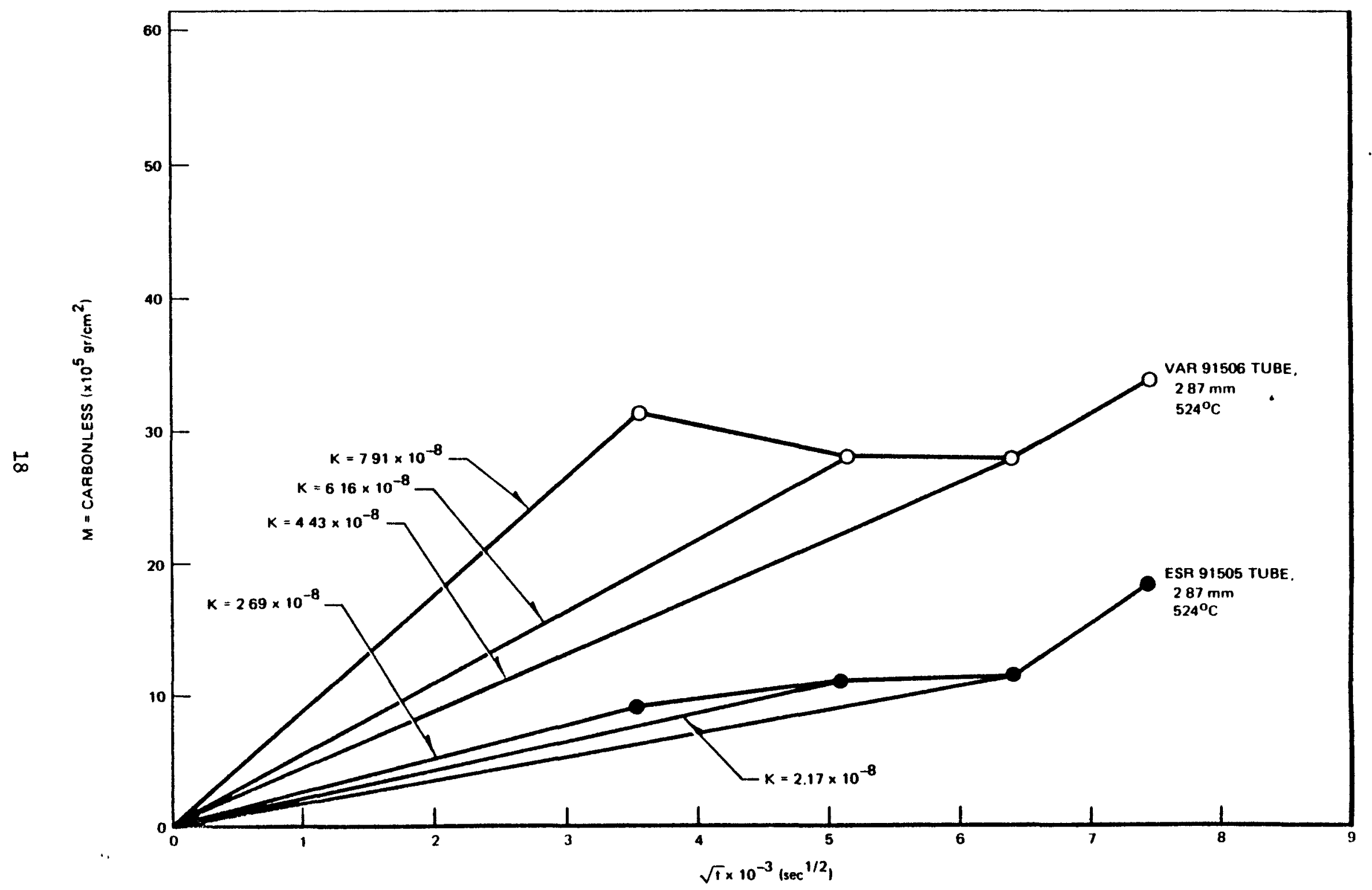

Figurc 1. Decarburization Rate Constants for 2-1/4 $\mathrm{Cr}-1$ Mo Steel - Time Dependence, Tubes (524 ${ }^{\circ} \mathrm{C}$ ) 
TEMPERATURE $\left({ }^{\circ} \mathrm{C}\right)$

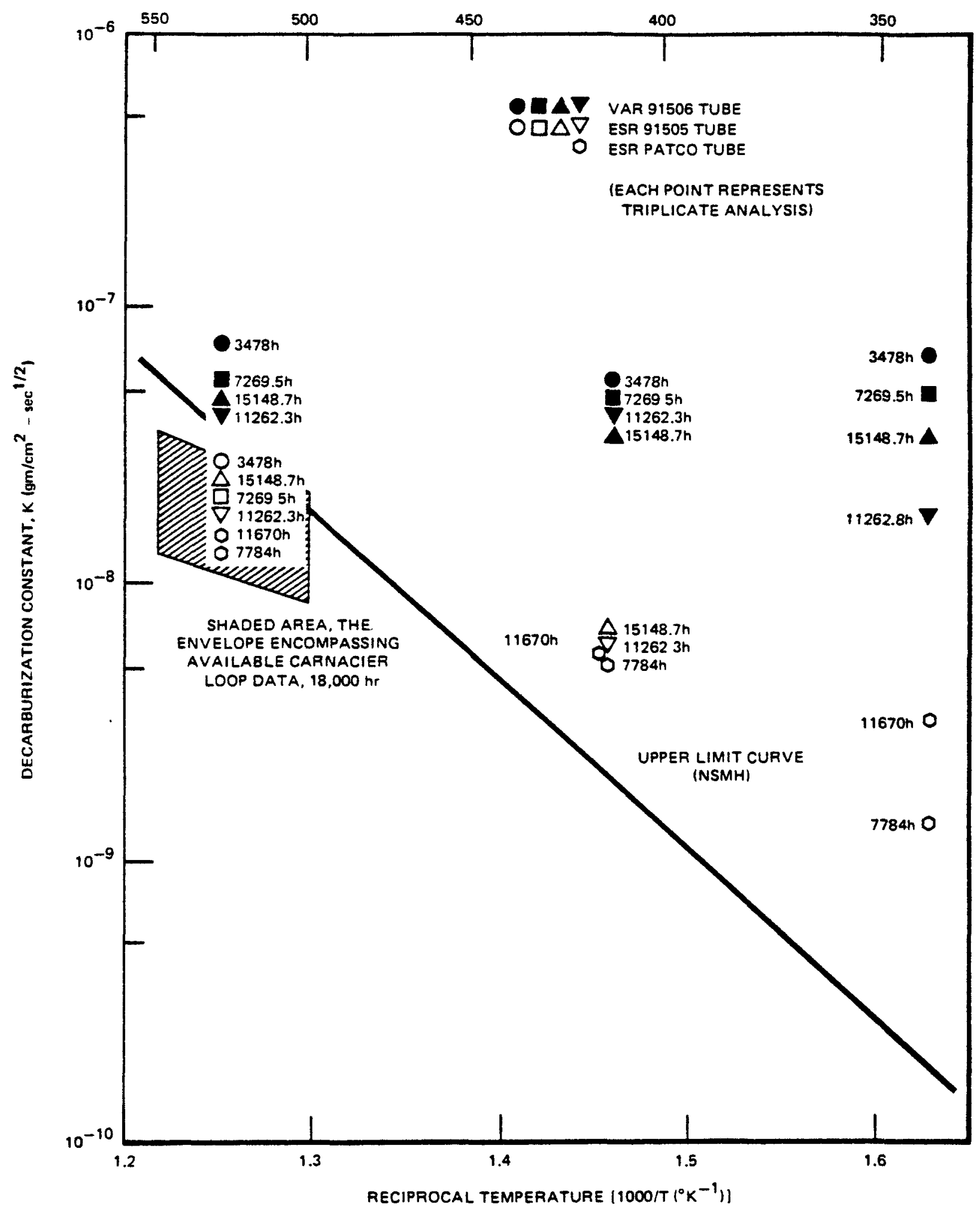

Figure 2. ISML Data After 15148 Hours 


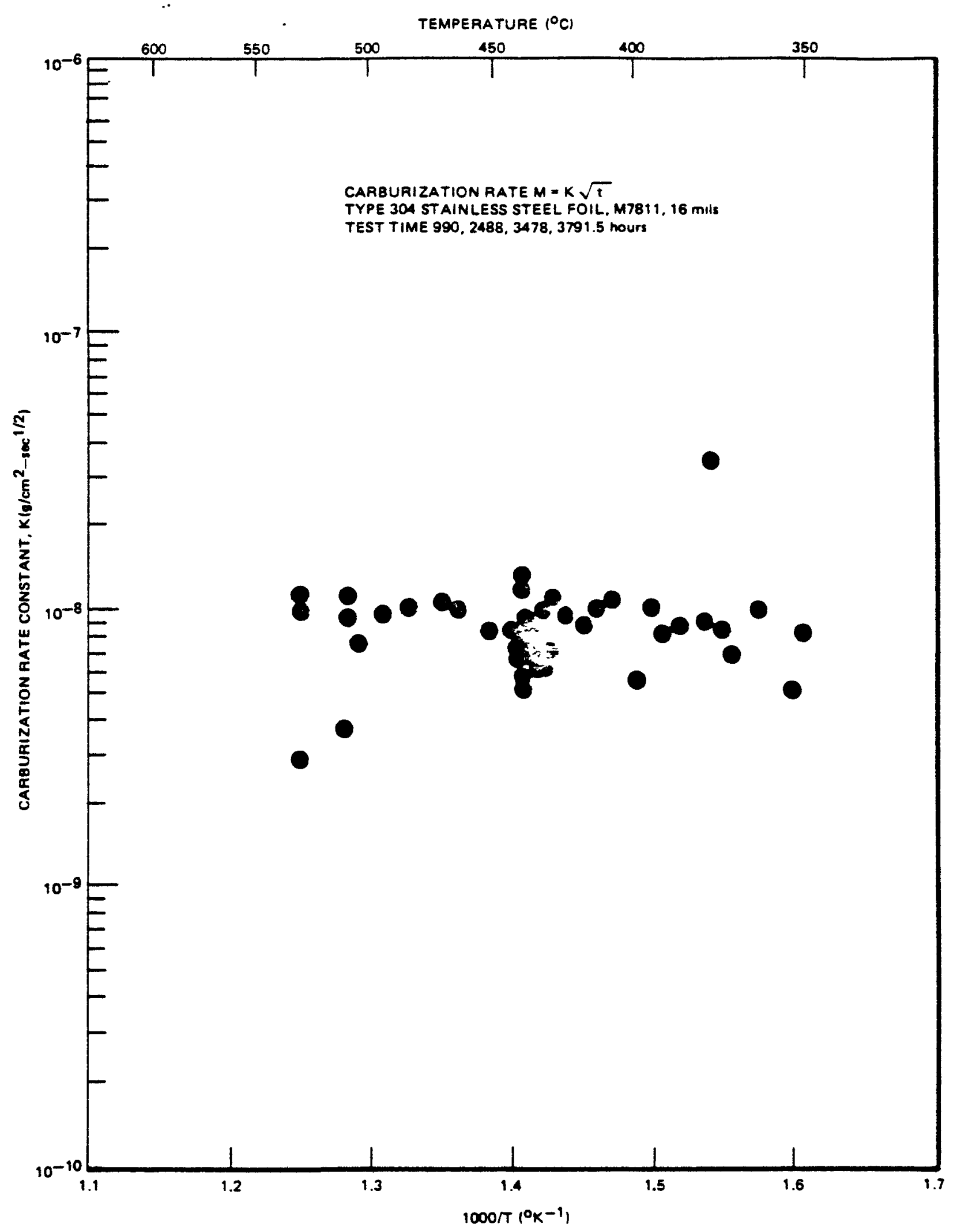

Figure 3. Relation Between Carburization Rate Constant and Temperature for Type 304 Stainless Steel 


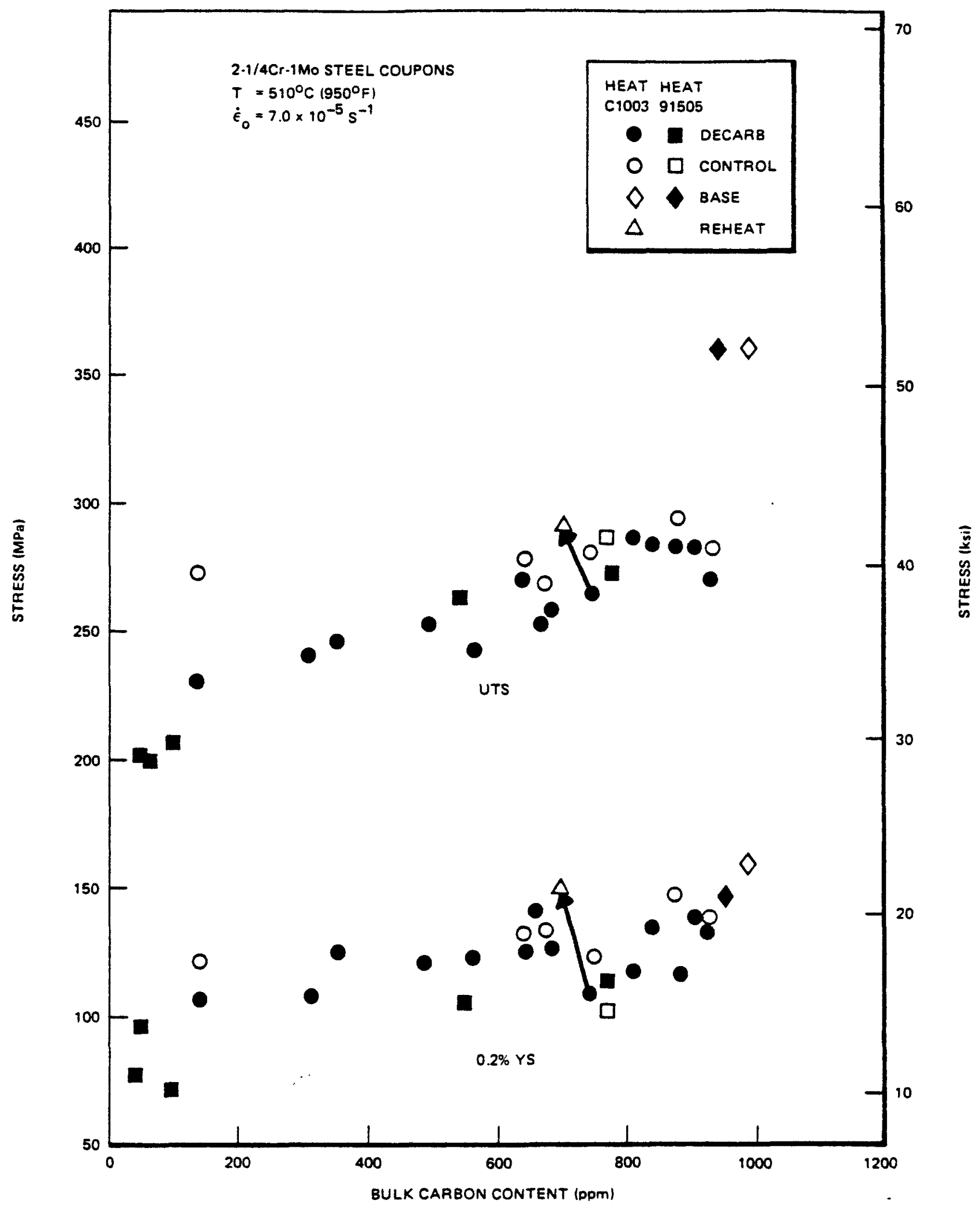

Figure 4. $510^{\circ} \mathrm{C}$ Coupon Data for Decarburized and Control 2-1/4Cr-1Mo 


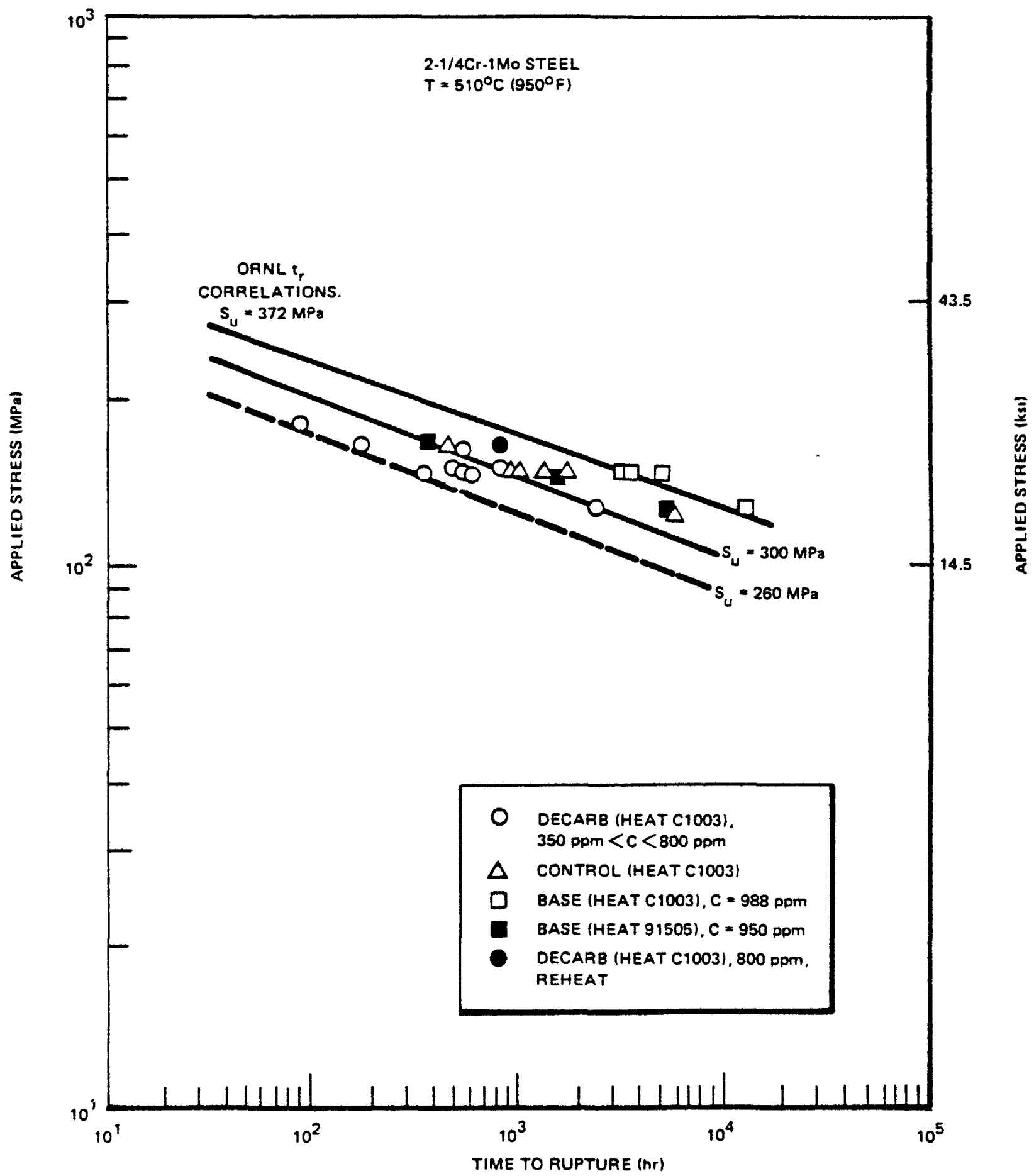

Figure 5. $510^{\circ} \mathrm{C}$ Stress Rupture Properties - Unexposed, Aged, Decarburized 2-1/4Cr-1Mo. Su Values Shown are for Unexposed ( $372 \mathrm{MPa}$ ), Therms 11 y Aged (300 MPa) and Decarburized (260 MPa) Material. 


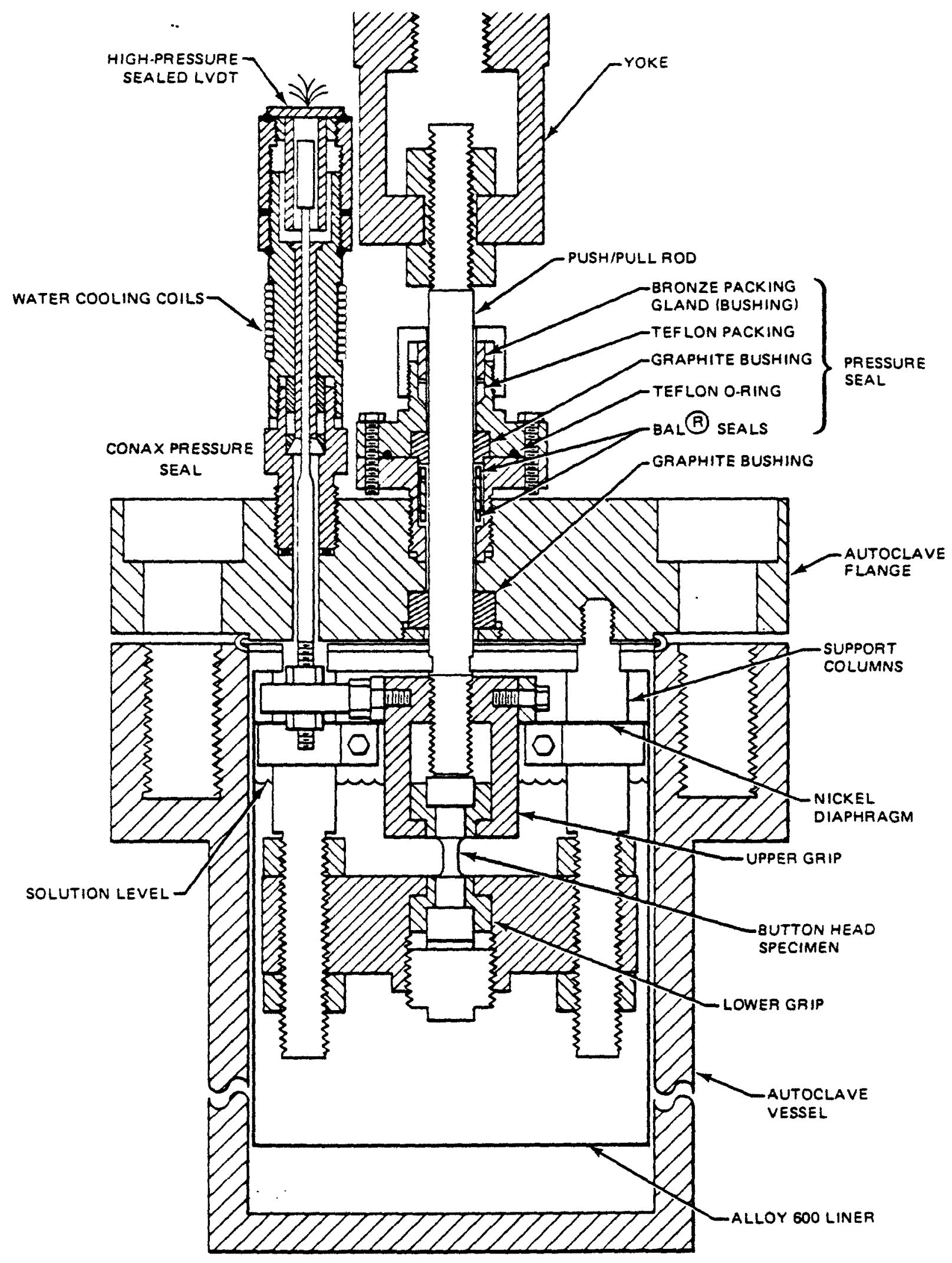

Figure 6. Schematic-Corrosion Fatigue Test Facility 


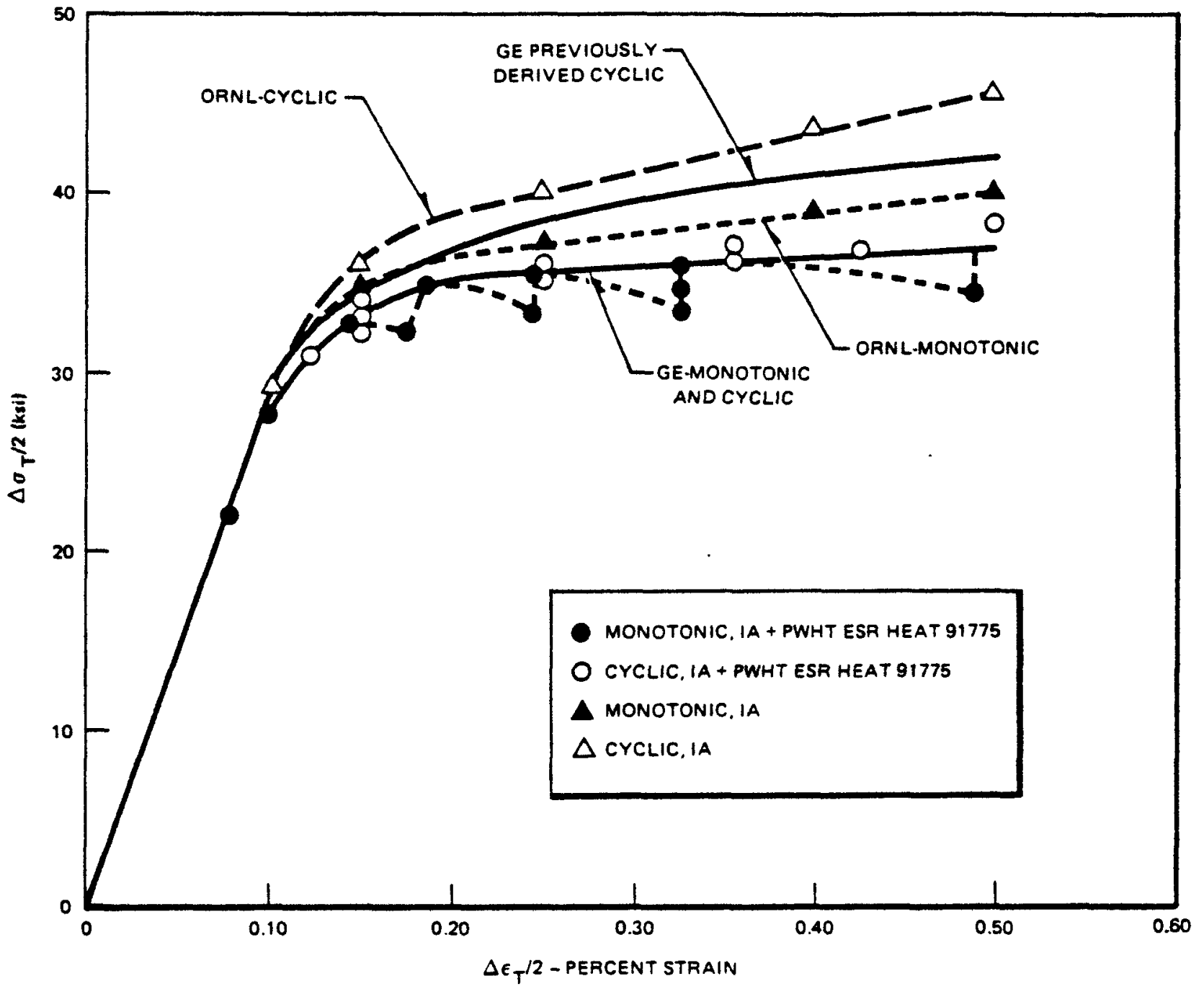

Figure 7. Monotonic and Cyclic Stress-Strain Curves in Air at $316^{\circ} \mathrm{C}\left(6 n 0^{\circ} \mathrm{F}\right)$ for $2-1 / 4 \mathrm{Cr}-1$ Mo Steel 


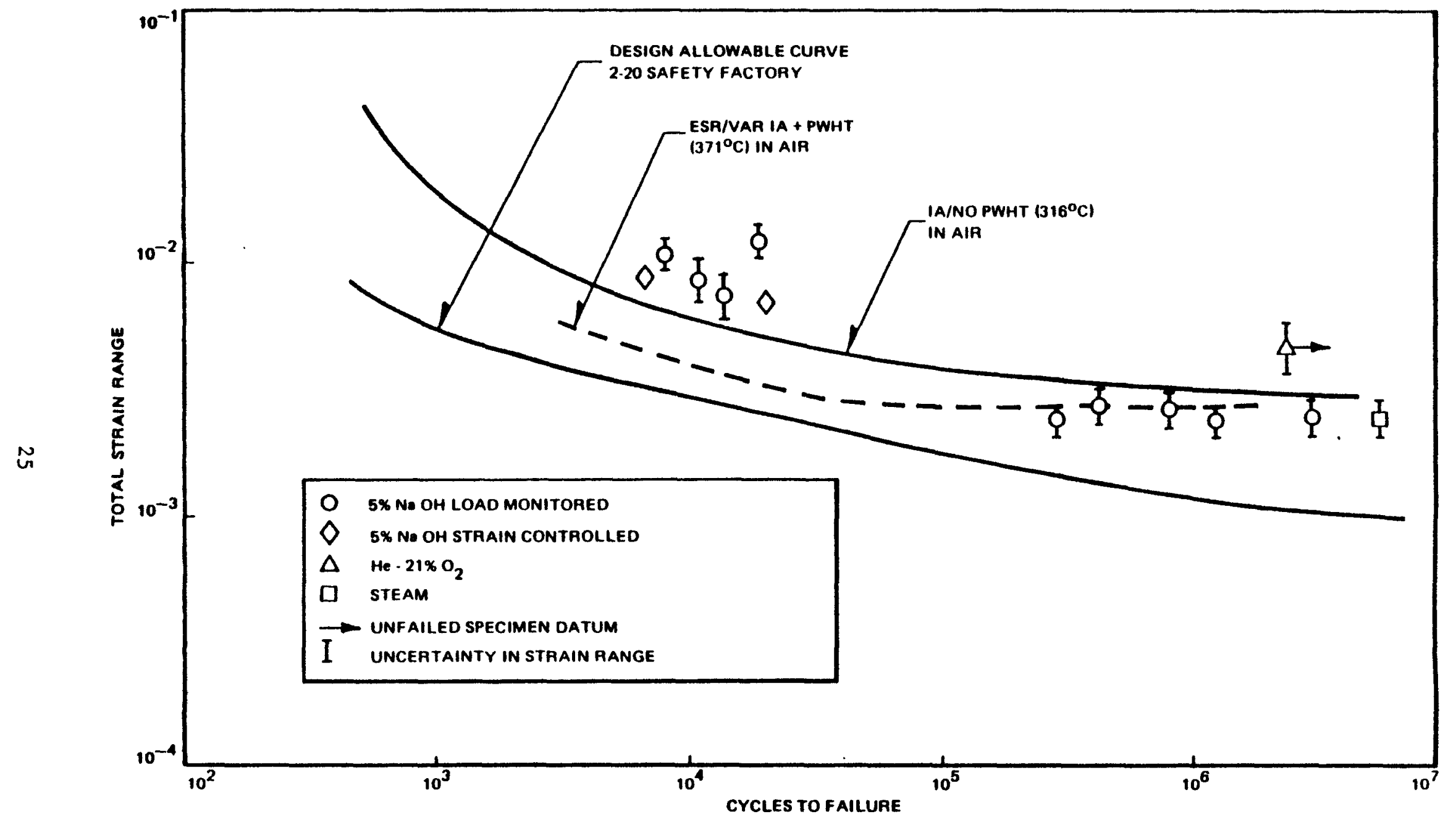

Figure 8. Results of Fully Reversed Cycled Corrosion Fatigue Tests in Deaerated 5\% Sodium Hydroxide at $316^{\circ} \mathrm{C}\left(600^{\circ} \mathrm{F}\right)$ for IA + PWHT 2-1/4Cr-1Mo Stee1 - Heat 91775 


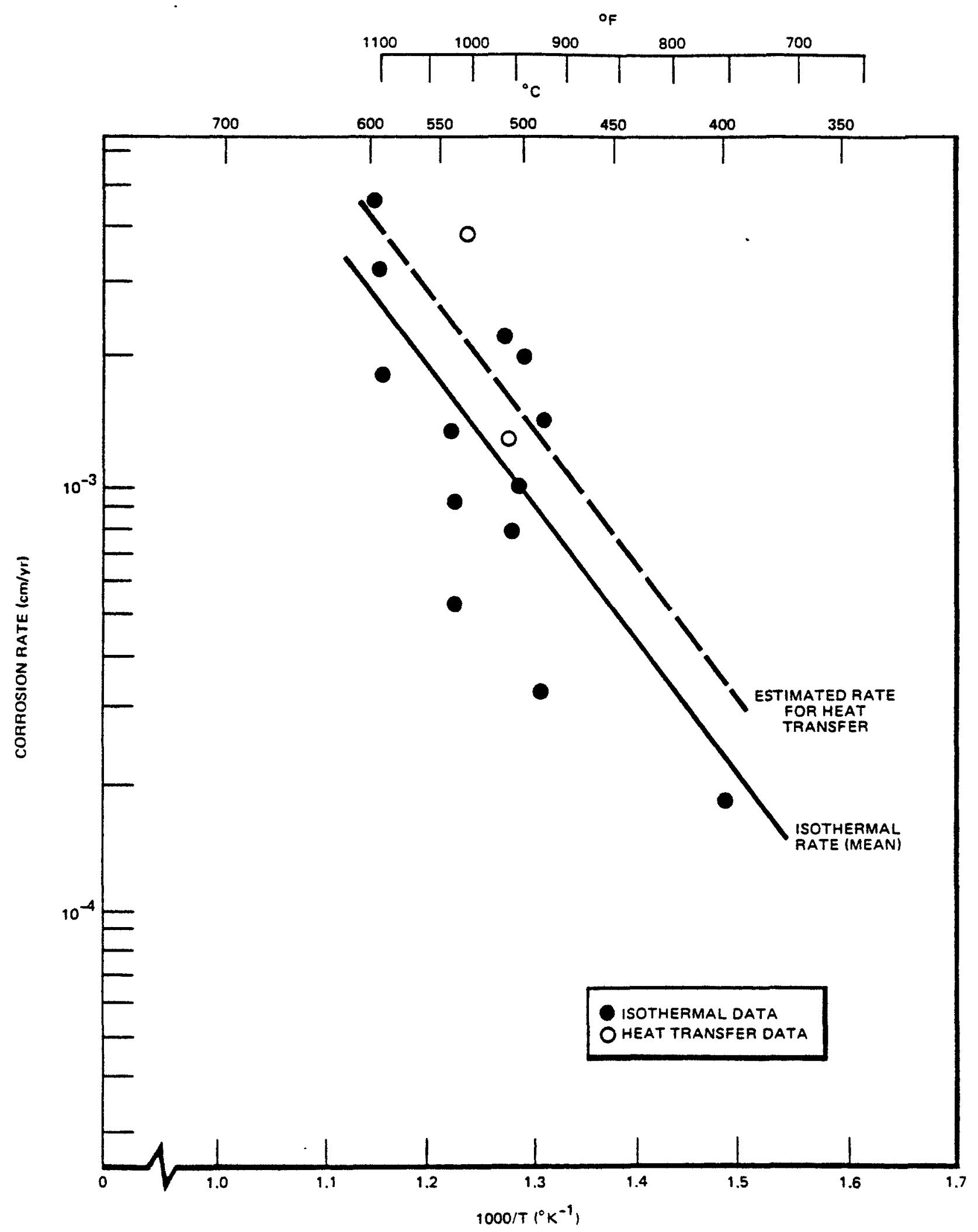

Figure 9. Steam Corrosion Rate Data for 2-1/4 Cr-1Mo Steel 
$\therefore i$

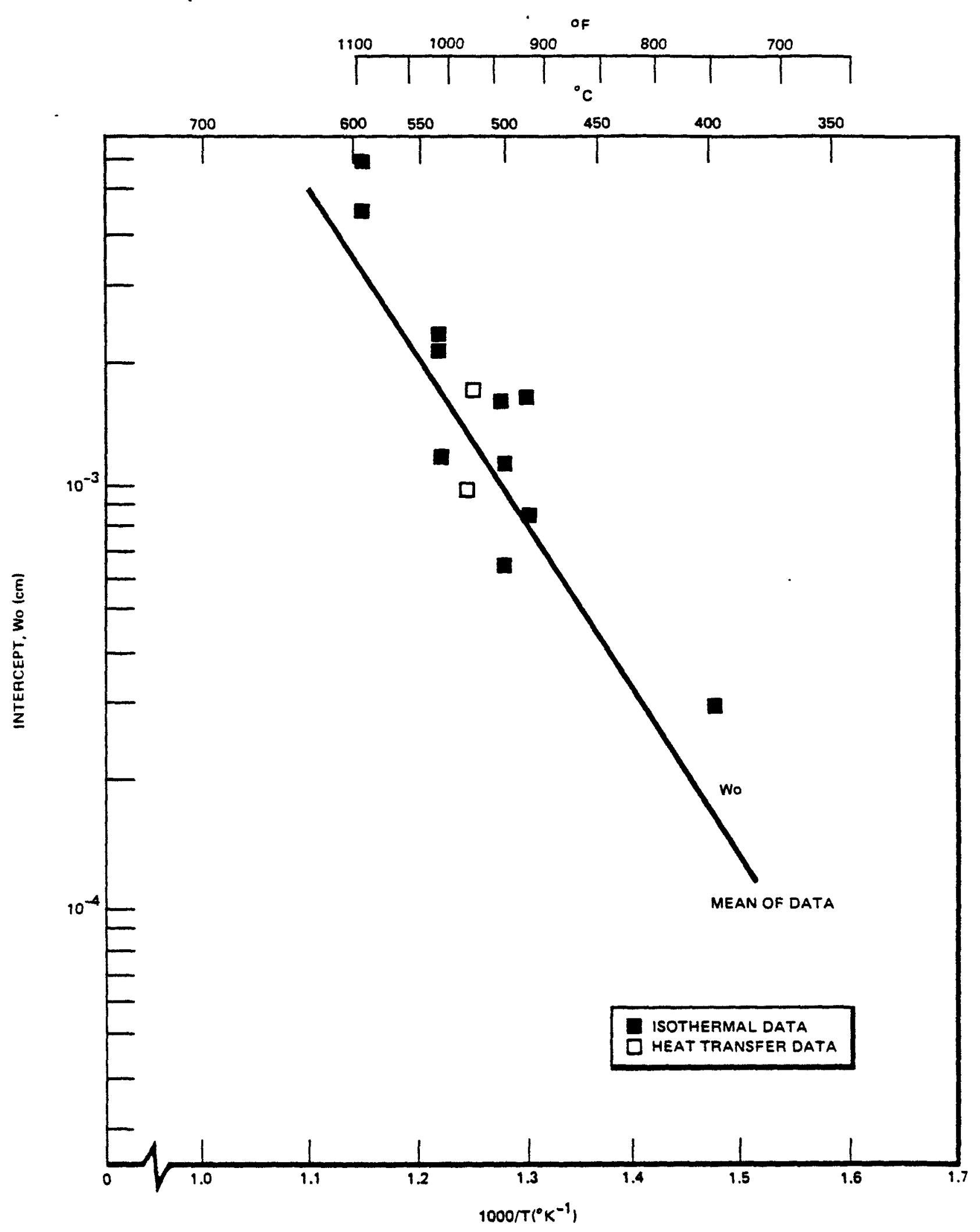

Figure 10. Intercepts of Corrosion Data for 2-1/4 Cr-1Mo Steel In Steam 